\title{
CARBONIC ANHYDRASE ACTIVITY IN THE GILLS OF ETROPLUS MACULATUS (TELEOSTEI) AS A FUNCTION OF SALINITY ACCLIMATION
}

\author{
BY R. V. KRISHNAMOORTHY * AND V. VIRABhadRACHARI \\ (Department of Zoology, Sri Venkateswara University, Tirupati, Andhra Pradesh, India) \\ Received November 27, 1968
}

(Communicated by Prof. S. Krishnaswamy, F.A.sc.)

\begin{abstract}
1. Carbonic anhydrase in the gills of the freshwater teleost, Etroplus maculatus, was demonstrated to be influenced by transfer of the animal to saline media.

2. Sudden and direct exposure of the fish to saline media resulted in a decrease of the enzyme activity.

3. The enzyme activity was reduced gradually with progressive increase of the salinity after two months acclimation of the fish in the medium.

4. It was concluded that reduced carbonic anhydrase activity of the gill on acclimation to higher salinities, is associated with $\mathrm{Cl}^{-}$uptake but not $\mathrm{Cl}^{-}$excretion.
\end{abstract}

\section{INTRODUCTION}

THE occurrence of carbonic anhydrase in teleostean gill was demonstrated several times (Van Goor, 1948, review; Jozuka, 1967; Maren, 1967, review) and the physiological processes of gas exchange and electrolyte transport have been shown to depend on the activity of this enzyme (Maren, 1967, review). $\mathrm{HCO}_{3}-\mathrm{Cl}^{-}$exchange was suggested to be the mechanism operating chloride transport in teleost gill (Maetz and Garcia Romeu, 1964). In the present investigation carbonic anhydrase activity was measured in the gill epithelium of the euryhaline fish Etroplus maculatus, adapted to different salinities with the hope that it might throw some light on the possible relationship between the carbonic anhydrase activity and the chloride regulation.

- Provent address: Department of Zoology, Bangalore University, Bangalore-1. 
Material and Methods

\section{Animal}

The fish, Etroplus maculatus, were purchased from the State Fisheries Department, Tirupati, Andhra Pradesh and stocked in laboratory aquaria. They are fed daily with Hydrilla plant, boiled rice and bits of earthworm.

\section{Acclimation}

The fish were transferred to different salinities in two different ways. Experiment (1): The fish were upgraded through different salinities by keeping them for $1 \mathrm{hr}$. in each salinity. The mortality was high when the fish were brought to $100 \%$ sea-water. Experiment (2): The fish were brought to higher salinities through intermediate salinities. They were kept for one week in each of intermediate salinities before they were transfered to the reported salinity. They were adapted to the reported medium for two months under normal condition of feeding.

\section{Enzyme Assay}

The carbonic anhydrase in the gills $(100 \mathrm{mg}$ wet weight) was purified by the method of Roughton and Booth (1946) and its activity was determined by the veronal indicator method of Roughton and Booth as described by Waygood (1955).

The enzyme was assayed in six different animals and the results were found to be consistent.

\section{Chloride Determination}

The chlorides in the medium and the blood of fish were titrated against standard Silver Nitrate potentiometrically, using Gallenkamp electrometric microtitration apparatus. The blood was collected from the dissicted fish with a heparinized glass capillary, through heart puncture. The blood from 3-4 specimens was pooled for the determination. All the dilutions of sea-water were made with tap-water, with sea-water of salinity of $32 \cdot 31 \%$.

\section{RESULTS}

The results of the first experiment were summarised in Table I. It is evident from the table that carbonic anhydrase activity is related to the chloride gradient. The enzyme activity decreased to about $1 / 3 \mathrm{rd}$ of the normal in redistilled-water medium. But it showed a $21 \%$ increase in $25 \%$ sea-water which may be a result of. sudden exposure of the animal to a 
new environment. This increase may be attributed to an overshoot response (Grainger, 1958). Transfer to other salinities resulted in the reduction of the enzyme activity. The mode of transfer did not alter the blood chloride levels.

The results of the second experiment were given in Table II. As is evident from this, the acclimation to higher salinities for two months brought a gradual decrease in the carbonic anhydrase activity of the gills. A maximum activity was recorded in freshwater medium and the minimum in full-strength sea-water. The blood chloride content was not altered by the medium of acclimation.

\section{Discussion}

It has been shown by Pampapathi Rao (1958) that the freshwater teleost, Etroplus maculatus, can tolerate transfer into undiluted and even concentrated sea-water without any apparent deleterious effects. The fish has a blood chloride concentration of $294 \mathrm{mM} / \mathrm{L}$ in its natural medium of freshwater which is quite high when compared to other freshwater fishes. Probably, this high concentration of the chlorides of blocd and tissues may be contributing to the eurysalinity of this fish (Parvatheswara Rao, 1965). Virabhadrachari (1961) demonstrated the "Chloride Cells" in the gills of $E$. maculatus adapted to sea-water and suggested that the gill is the extrarenal pathway of chloride excretion. He also suggested a reversal of physiological polarity of these "Chloride Cells" of the fish in freshwater, during acclimation to hyper-osmotic media.

It was shown that the freshwater teleost takes up $\mathrm{Cl}^{-} / \mathrm{Na}^{+}$independently and these ions are exchanged with $\mathrm{HCO}_{3}-/ \mathrm{NH}_{4}{ }^{+}$respectively (Krogh, 1939; Garcia Romeu and Maetz, 1964; Maetz and Garcia Romeu, 1964). Flemister (1959) reported similar ion exchange mechanism in the gills of the crab, Ocypode albicans. Carbonic anhydrase activity is the incumbent of this ion exchange (Maetz and Garcia Romeu, 1964; Maren, 1967). Carbonic anhydrase inhibition produces significant plasma-chloride increase in the marine fish, Serranus (Maetz, 1953) and a decrease in the freshwater Perca (Maetz, 1956).

The results of the present investigation (Table I) show that carbonic anhydrase activity is higher in the media when active chloride uptake is necessary. On sudden transfer to the $50 \%$ sea-water which is nearly isoionic, there is nearly $49 \%$ inhibition of carbonic anhydrase activity which is maintained still at relatively higher level in $75 \%$ sea-water (i.e., $53 \%$ ) and 
in full-strength sea-water (i.e., $57 \%$ ). The low enzyme activity in distilled water may probably due to the adverse effects.

\section{TABLE I}

Carbonic anhydrase activity in the gill of Etroplus maculatus subjected to sudden salinity stress for one hour

\begin{tabular}{llccc}
\hline Medium of stress & $\begin{array}{c}\text { Rate of enzymic } \\
\text { hydration of } \\
\mathrm{CO}_{2}(\mathrm{M} / 1 / \mathrm{sec})\end{array}$ & $\begin{array}{c}\text { Cl- gradient } \\
\text { (blood chl.-medium } \\
\text { chl.) mM/1 }\end{array}$ & $\begin{array}{c}\% \text { activity } \\
\text { of } \\
\text { F.W. }\end{array}$ \\
\hline 1. Distilled water & $\ldots$ & $1.073 \times 10^{-5}$ & +294 & 35 \\
2. Freshwater & $\ldots$ & $3.04 \times 10^{-5}$ & +280 & 100 \\
3. $25 \%$ sea-water & $\ldots$ & $3.66 \times 10^{-5}$ & +155 & 120 \\
4. $50 \%$ Sea-water & $\ldots$ & $1.58 \times 10^{-5}$ & +30 & 51 \\
5. $75 \%$ Sea-water & $\ldots$ & $1.45 \times 10^{-5}$ & -95 & 47 \\
6. Full-strength sea-water & $1.303 \times 10^{-5}$ & -220 & 43 \\
\hline
\end{tabular}

Prolonged sojourn in different salinities (Table II) elicits essentially a similar kind of response in the enzyme activity, in that the carbonic anTABLE II

Carbonic anhydrase activity in the gill of Etroplus maculatus on acclimation to different salinities for two months

$\begin{array}{lccc}\text { Medium of } & \begin{array}{c}\text { Chloride } \\ \text { gradient } \\ \text { (blood chl.- } \\ \text { medium chl.) }\end{array} & \begin{array}{c}\text { Rate of enzymic } \\ \text { hydration of } \\ \text { carbon dioxide } \\ (\mathrm{M} / 1 / \mathrm{sec} .)\end{array} & \begin{array}{c}\% \text { activity } \\ \text { of }\end{array} \\ \text { F.W. }\end{array}$

1. Freshwater

$+280$

$3.04 \times 10^{-5}$

100

2. $25 \%$ Sea-water

. +155

$2 \cdot 55 \times 10^{-5}$

84

3. $50 \%$ Sea-water

. +30

$2 \cdot 30 \times 10^{-5}$

76

4. $75 \%$ Sea-water

.. -95

$1.94 \times 10^{-5}$

64

5. $100 \%$ Sea-water

.. -220

$1.65 \times 10^{-6}$ 
hydrase activity decreases with progressive increase in salt concentrations of the acclimation media. The decrease is gradual and the enzyme activity in different salinities was observed to be slightly higher than those of the values obtained (Table I) on sudden direct transfer.

The results (Tables I and II) clearly show that there exists a close relationship between the chloride balance and carbonic anhydrase activity. The higher enzyme activity in freshwater and 25\% sea-water appears to be linked to the chloride uptake mechanism. In higher salinities $(75 \%$ and $100 \%$ sea-water), which are hyper-ionic to the fish, it is the chloride exclusion that is more important and the lack of chloride uptake is reflected by the low enzyme activity. The low enzyme activity in higher salinities also indicates that carbonic anhydrase activity is not related to the mechanism of chloride exclusion; but only associated with the chloride uptake.

\section{ACKNOWLEDGEMENTS}

The authors wish to thank Dr. R. Ramamurthi, Department of Zoology, Sri Venkateswara University, for many helpful suggestions. One of the authors (R. V. K.) gratefully acknowledges the Council of Scientific and Industrial Research of India for placement in the Scientists' Pool. We are thankful to Prof. S. Krishnaswamy, F.A.sc., Head of the Department of Zoology, Madurai University, for kindly going through the manuscript and forwarding it for publication.

\section{REFERENCES}

1. Flemister, S. C. $\quad$. "Histophysiology of gill and kidney of crab, Ocypode alblcans," Biol. Bull., 1959, 116, 37-48.

2. Garcia Romeu, F. and Maetz, J.

"The mechanism of sodium and chloride uptake by the gills of a freshwater fish, Carassius auratus. 1. Evidence for an independent uptake of sodium and chloride ions," J. gen. Physiol., 1964, 47, 1195-1207.

3. Grainger, J. N. R.

.. "The initial metabolic responses to temperature change in poikilotherms," in Physiological Adaptation (Ed., C. L. Prosser), Washington, American Physiological Society,
1958, pp. 79-90.

4. Jozuka, $\mathrm{K}$.

.. "Chloride regulation by the gill of the freshwater teleost, Carassins auratus," Annot. Zoo. Japon, 1967; 40, 205-10.

5. Krogh, A.

- Osmotic Regulation in Agatic Animals, Cambridge University
Press, London, 1939.

6. Maetz, J. .. As quoted by Maetz and Romeu (1964), 1953, 
7. Maetz, J. $\quad$.. "Les echanges de sodium chez le poisson Carrasius auratus. Action d'um inhibite ur de L'anhydrase carbonique," $J$. Physiol. Paris, 1956, 48, 1085-99.

8. _ and Garcia Romeu, "The mechanism of sodium and chloride uptake by the gills F. of a freshwater fish Carassins auratus. II. Evidence for $\mathrm{NH}_{4}{ }^{+} / \mathrm{Na}^{+}$and $\mathrm{HCO}_{3}-/ \mathrm{Cl}^{-}$exchanges," J. gen. Physiol., 1964, 47, 1209-27.

9. Maren, T. H.

.. "Carbonic anyhydrase: Chemistry, physiology and inhibition," Physiol. Revs., 1967, 47, 595-781.

10. Pampapathi Rao, K. .. "Salinity tolerance of Etroplus maculatus (Bloch.)," Curr. Sci., 1958, 27, 99.

11. Parvatheswara Rao, V. .. "Influence of different temperature-salinity combinations on the oxygen consumption in the freshwater fish Etroplus maculatus (Teleostei)," Helgol. wiss. Meerasunters, 1965, 12, 301-14.

12. Roughton, F. J. W. and Booth, V.H.

"The effect of substrate concentration, $\mathrm{pH}$ and other factors upon the activity of carbonic anhydrase," Biochem. J., 1946, 40, 319-30.

13. Van Goor, $\mathrm{H}$.

.. "Carbonic anhydrase, its properties, distribution and significance for carbon dioxide transport," Enzymologia, 1948, 13, 73-164.

14. Virabhadrachari, V. .. "Structural changes in the gills, intestine and kidney of Etroplas maculatus (Teleostei) adapted to different salinities," Quart. J. Micr. Sci., 1961, 102, 361-69.

15. Waygood, E. R.

.. In Methods in Enzymology (Edrs. S. P. Colowick and N. O. Kaplan), Academic Press, Inc., New York, 1955, 2, 839. 